\title{
Investigating the working Conditions Using the ILO Checklist Based on the Interventional Approach of Participatory Ergonomics and its Impact on the Quality of Working Life and Musculoskeletal Disorders
}

\author{
Mohammad Babamiri ${ }^{1}$, Fakhradin Ghasemi ${ }^{2}$, Rashid Heidari Moghadam ${ }^{1}$, Jalil Derakhshan*3, $^{* 3}$ \\ Mahnoush Karimi ${ }^{3}$
}

1. Health Sciences Research Center, Department of Ergonomics, School of Health, Hamadan University of Medical Sciences, Hamadan, Iran

2. Occupational Health and Safety Research Center, Department of Ergonomics, School of Health, Hamadan University of Medical Sciences, Hamadan, Iran

3. MSc of Occupational Health Engineering, School of Health, Hamadan University of Medical Sciences, Hamadan, Iran

\begin{tabular}{|c|c|}
\hline Info & ABSTRACT \\
\hline $\begin{array}{c}\text { Received: } 18 \text { July } 2017 \text {; } \\
\text { Accepted: } 29 \text { May. 2018; } \\
\text { Published Online 2018/05/29 } \\
\text { DOI: } 10.30699 / \text { jergon.5.4.49 }\end{array}$ & $\begin{array}{l}\text { Background: "Participatory ergonomics" is defined as an active participation of } \\
\text { all members of the organization in the development and implementation of } \\
\text { ergonomic knowledge in order to improve the working environment, quality, } \\
\text { productivity and safety of the organization. The purpose of this study was to } \\
\text { determine the appropriate process of working condition with the participatory } \\
\text { ergonomic approach and its impact on one of the printing industries. }\end{array}$ \\
\hline $\begin{array}{l}\text { Use your device to scan } \\
\text { and read the article online }\end{array}$ & $\begin{array}{l}\text { Methods: This research is an interventional study carried out in one printing } \\
\text { industry center. To identify the ergonomic risk factors the "Nordic Questionnaire" } \\
\text { and "Ergonomic Review Points" and to evaluate the quality employees' working life, } \\
\text { the NIOSH modified quality of life curriculum was used. The results were by } \\
\text { conducting a paired t-test using SPSS } 20 \text { software package. } \\
\text { Results: The investigation of health, and working conditions using the } \\
\text { supplementary checklist before and after applying the review points with } \\
\text { participatory ergonomic approach shows a significant increase. Data analysis using } \\
\text { the paired t-test showed a significant improvement in quality of working life and }\end{array}$ \\
\hline Correspond & reduction of musculoskeletal disorders after intervention $(P<0.001)$ \\
\hline Jalil Derakhshan & Conclusion: According to the results, it can be concluded that the individuals' \\
\hline $\begin{array}{l}\text { MA of Occupational Health } \\
\text { Engineering, School of } \\
\text { Health, Hamadan University } \\
\text { of Medical Sciences, } \\
\text { Hamadan, Iran } \\
\text { Email: }\end{array}$ & $\begin{array}{l}\text { social skills and abilities have increased by participation in the process of } \\
\text { participatory ergonomics. Increasing the quality of working life has a significant role } \\
\text { to improve the health of workers and reduce occupational accidents. Therefore, the } \\
\text { implementation of participatory ergonomic program with the collaboration of } \\
\text { industrial managers can be an effective step towards achieving human resource } \\
\text { satisfaction and health. }\end{array}$ \\
\hline & $\begin{array}{l}\text { Keywords: Participatory Ergonomics, Quality of Working Life, Musculoskeletal } \\
\text { Disorders }\end{array}$ \\
\hline
\end{tabular}

Copyright ( ) 2018, Journal of Ergonomics. This is an open-access article distributed under the terms of the Creative Commons Attribution-noncommercial 4.0 International License which permits copy and redistribute the material just in noncommercial usages, provided the original work is properly cited.

\section{How to Cite This Article:}

Babamiri M, Ghasemi F, Heidari Moghadam R, Derakhshan J, Karimi M. Investigating the working Conditions Using the ILO Checklist Based on the Interventional Approach of Participatory Ergonomics and its Impact on the Quality of Working Life and Musculoskeletal Disorders. J Ergon. 2018; 5 (4): 49-55 
بررسى شر ايط كارى با استفاده از جكليست ILO با رويكرد مبتنى بر برناملُ مداخلهاى اركونومى مشاركتى و

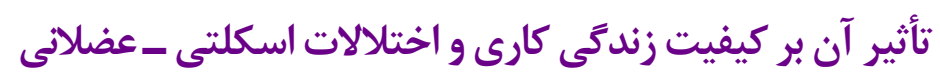

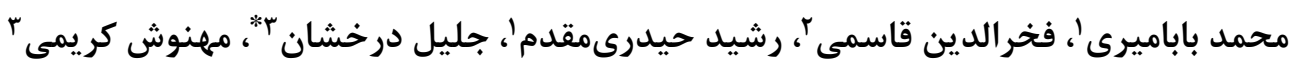

ا. مركز تحقيقات علوم بهداشتى، كروه اركونومى، دانشكدة بهداشت، دانشخاه علوم يزشكى همدان، همدان، ايران

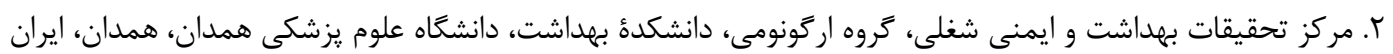

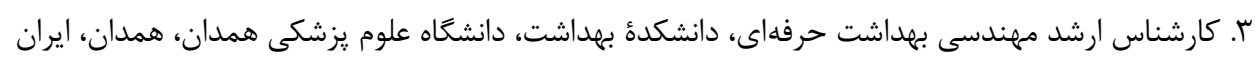

\begin{tabular}{|c|c|}
\hline خلاصه & اطلاعات مقاله \\
\hline 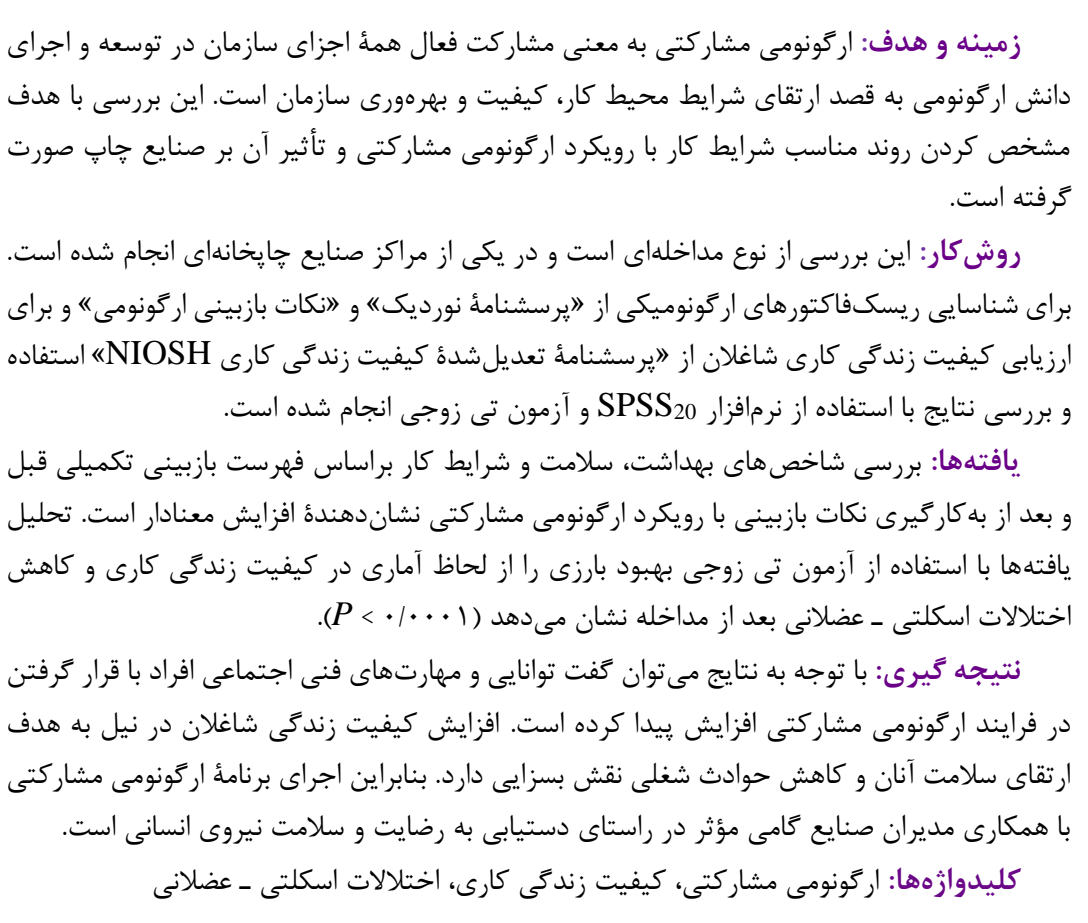 & 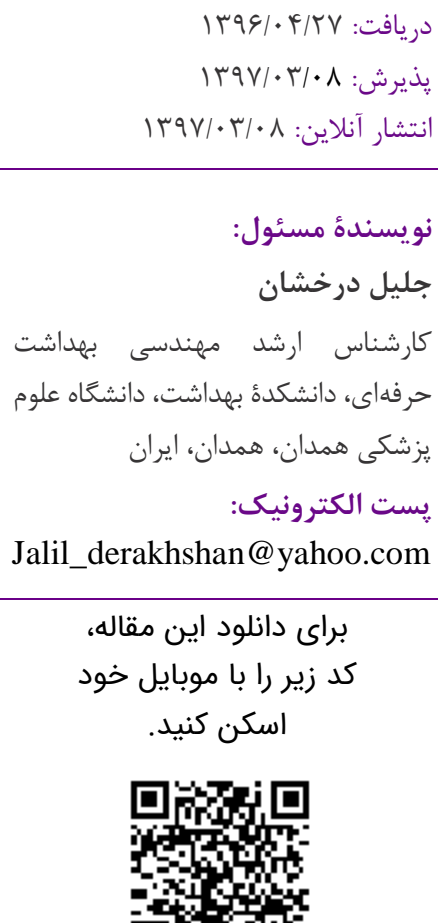 \\
\hline
\end{tabular}

تبديل شده است. طبق پيشبينى سازمان بينالمللى كار هر ساله حدود س/ץ ميليون كارگر در نتيجة حوادث (ILO) شغلى و بيمارىهاى مرتبط با كار جان خود را از دست مى دهند. از طرفى ميزان بروز حوادث شغلى منجر به مرى مرى در كشورهاى درحالتوسعه r تا F برابر كشورهاى توسعهيافته است. اين حوادث معمولاً بهصورت غير عمد اتفاق مى دافتد. در

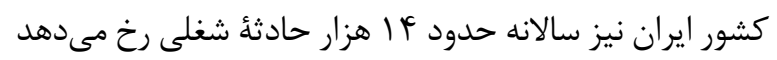

هلالى به توسعة انواع جكليستها بهعنوان ابزار اولويتبندى طرحهاى عملى اشاره كرده و جنين نظر داده
دسترسى سازمانها به دانش ارگونومى مخصوصاً در كشورهاى درحالتوسعه با مشكل مواجه است و بنابراين ارتقاى سطح آكاهى براى به كارگيرى ارگونومى به قصد اصلاح

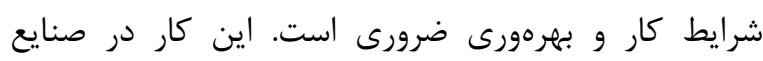
كشورهاى درحالتوسعة صنعتى، بهخصوص ايران ضرورت

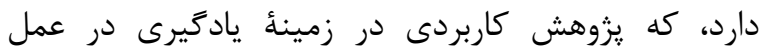

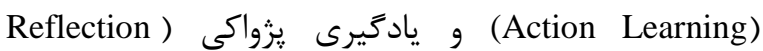
(Learning مورد نياز است [1]. امروزه مخاطرات ناشى از كار ئرى

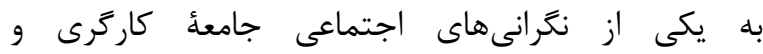
دستاندركاران مسائل بهداشت، سلامت و ايمنى محيط كار 
شاغلان را افزايش مىدهد و كيفيت محصولات توليدى و بهرهورى و كارايى را نيز در صنايع بهبود مىبخشد. بررسىهاى

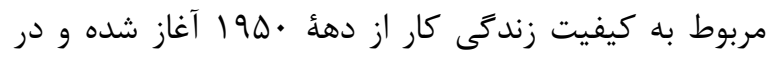
سالهاى اخير رواج زيادى ييدا كرده و دانشمندانى نظير والتون و استيفن رابينز روشهايى براى سنجش كيفيت زندگى كارى تدوين كردهاند [V]]. در تعريف كلى مىتوان كفت كيفيت زندكى كارى به معنى تصور ذهنى و برداشت كاركنان سازمان از مطلوبيت فيزيكى و روانى محيط كار و شرايط كار

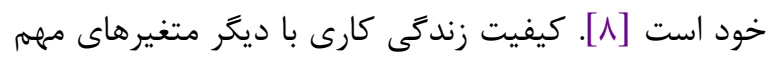
شغلى و سازمانى مانند رضايت شغلى، قصد ترك شغل، ميزان گردش مالى، شخصيت و استرس ناشى از كار مرتبط است

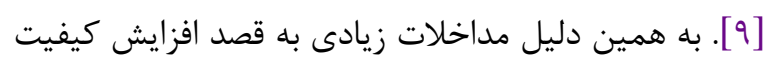

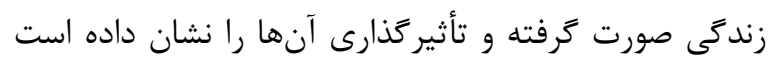
[ [ 11 . $11 \cdot]$

بلهرغم بررسى هاى متعدد در زمينهُ ار گونومى مشاركتى در

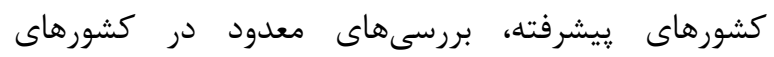
درحالتوسعه ازجمله ايران انجام شده است. از آنجايى كه دئن يايين بودن رضايت شغلى و كيفيت زندگى كارى از دلايل بى احتياطى شاغلان و ايجاد حادثه است؛ يزوهش در در زمينه روشهاى ارتقاى كيفيت زندگى كارى شاغلان و كاهش

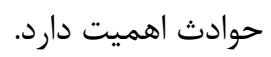

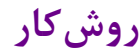

اين بررسى از نوع توصيفى ـ تحليلى و مداخلهاى است كه

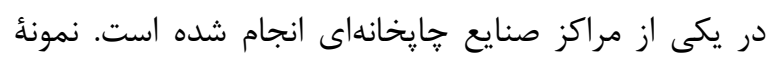
مورد بررسى •4 نفر بودند كه به روش تمامشمارى انتخاب شدند. جامعأ يزوهش را همأ شاغلان صنعت خايخانه بهاجز

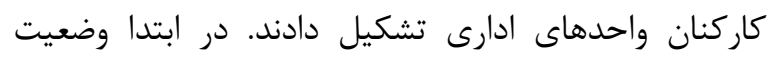

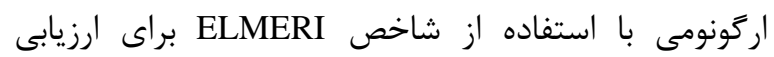

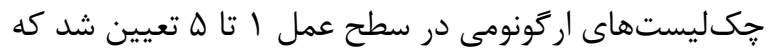

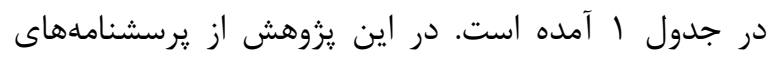
محققساخته شامل دو بخش اطلاعات دموگر افيك و سؤالات

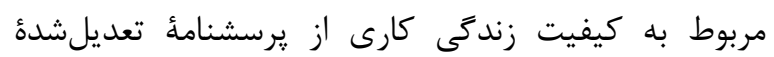

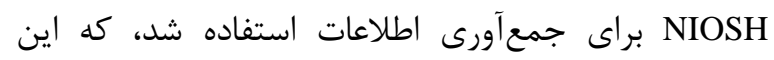
سؤالات شامل شاخصهاى عمده به شرح زير است: 1.

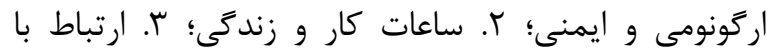

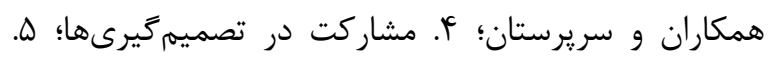

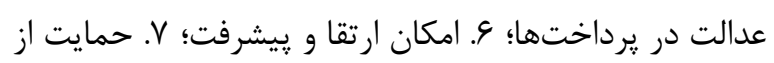

است كه مىتوان از فهرستهاى بازبينى با مشاركت فعال

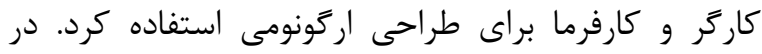

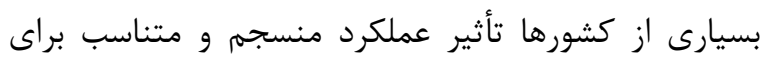
بهبود كار، بلويزه در كاركاههاى كوجى و متوسط در آسيا اثبات شده است. لذا روش بازبينى اركونومى سازمان

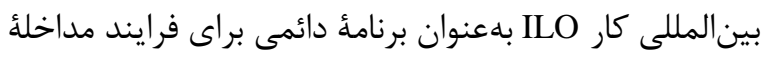
اركونومى به كار مىرود [ب]. از روشهاى كاهش مواجهات اركونوميكى در محيط كار،

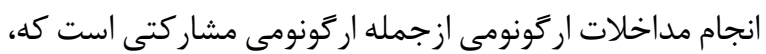

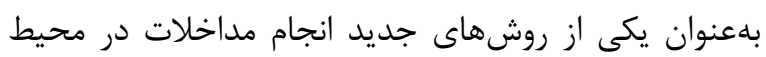

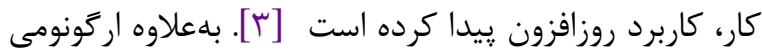

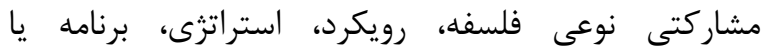

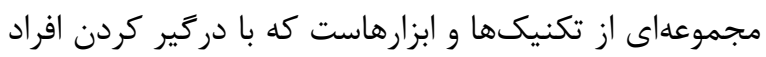
در طراحى و كنترل فعاليتهاى كارى، توأم با دانش و قدر بدرت

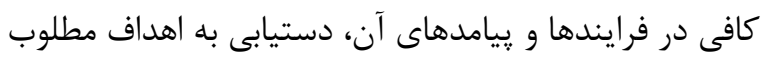

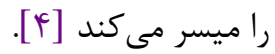
هلالى نشان داد كه يكى از روشهاى رئ جديد مطرحشده

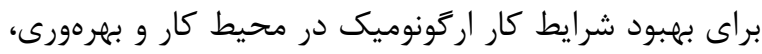

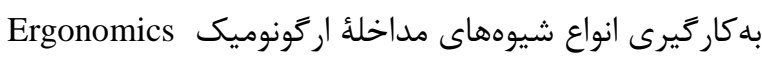
Intervention Techniques (EITs)

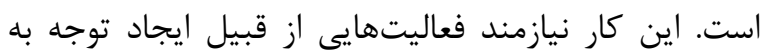

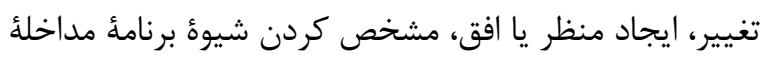

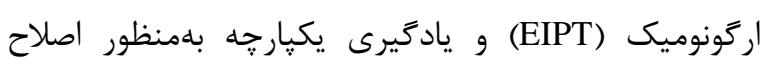

$$
\text { سيستمهاى كارى است [ه]. }
$$

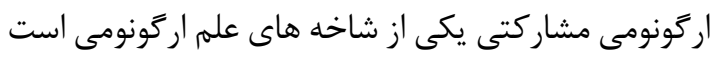

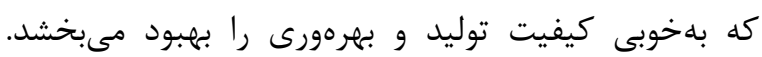

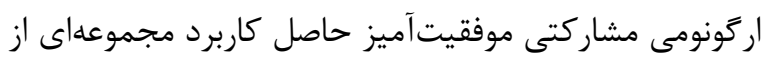
فرايندها و تكنيكها براساس مجموعهاى از الزامات و اصول

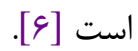
انسان سالم ركن اساسى توسعهُ پايدار و ارتقاى سطح

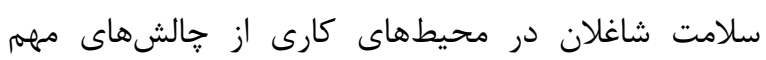

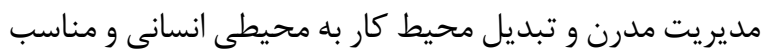

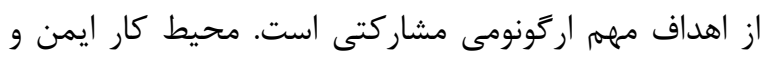

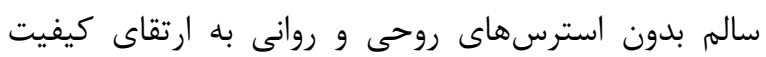
زندگى كارى (Quality Work Life) شاغلان نيز منجر الفر

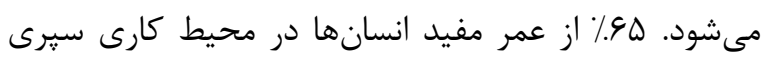

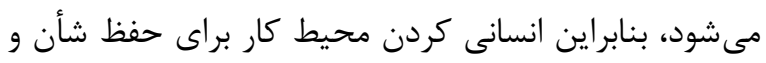

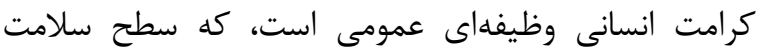


با كليات ارگونومى و سازماندهى و بهبود شرايط كار و تغيير

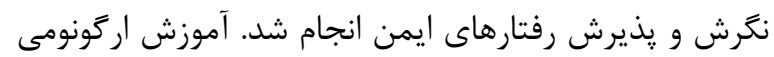

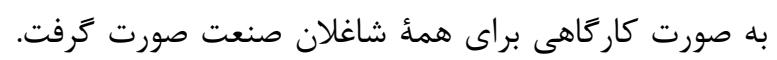

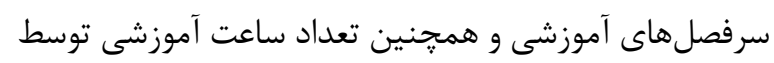

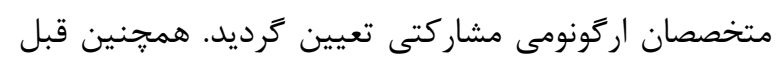
از آموزش و هنگام تحويل يرسشنامههاى كيفيت زندكى كارى

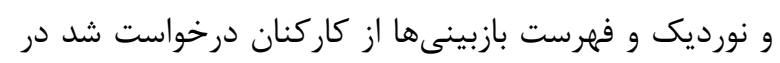
يايين و قسمت خالى يرسشنامهها مشكلات شرايط كار را به به همراه راهحل يُشينهادى ذكر كنند و سيس با تشكيل جلسات

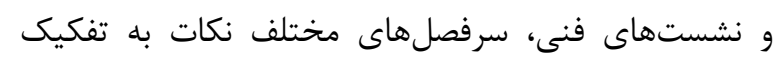

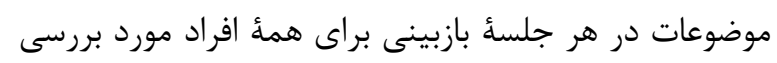

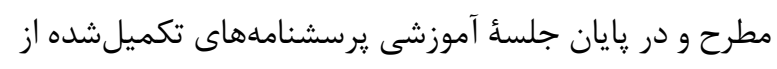

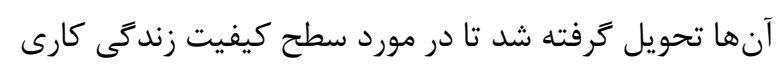

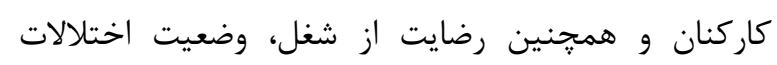

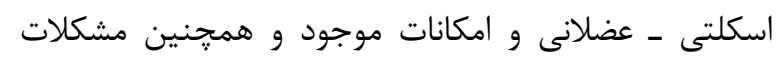
مربوط به شرايط كار و راهحلهاى بيشنيهادى خود كاركنان

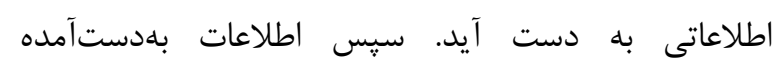
دستهبندى شد و در اختيار تيم راهبرى قرار زرفت. يس از داز اينكه مشكلات و راهحلهاى ييشنههادى نهايى شد و به تأييد بخش مديريت رسيد، به صورت برنامهٔ اجرايى زمانبندى و تفكيك مسئوليت شد تا در طول شش ماه و با توجه به اهميت مشكل به مرحلة اجرا درآيد. يس از كذشت شش ماه ماه اين

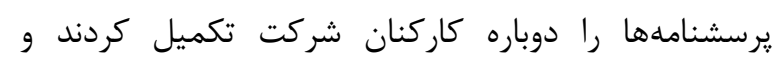
اطلاعات بلهدستآمده از يرسشنامههاى تكميلشده درأ در مرحلة

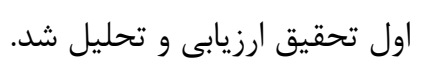

طرف مديريت و سريرستان؛ ^. رضايت شغلى و استفاده از

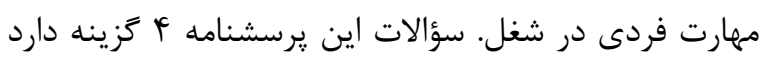

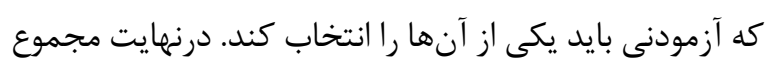
امتياز اكتسابى فرد نشاندهنده وضعيت كيفيت زندگى كارى يلى إنى اوست. كسب نمرء كمتر از · ب نشاندهنده كيفيت زندكى

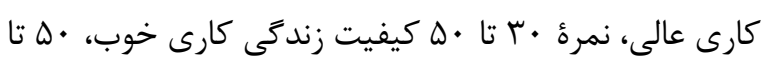

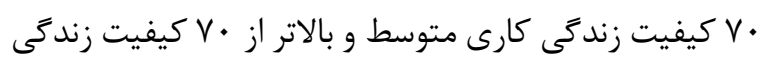

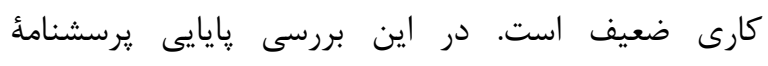
تعديلشده كيفيت زندگى كارى NIOSH، كه براى شرايط كارى صنعت مورد نظر است، از طريق تست مجدد (-) Test Re (Test

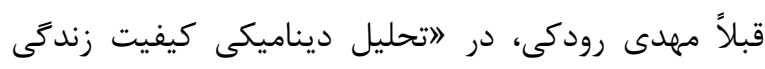
كارى" و يوسف همتجو، در "بررسى كيفيت زندگى كارى

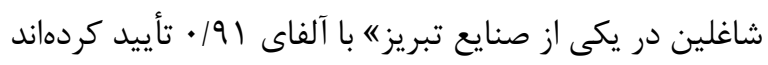

از آنجايى كه آموزش از اركان اصلى اجراى ارگتونومى

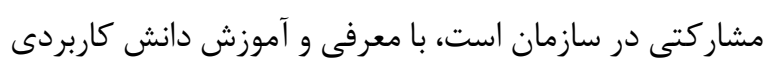

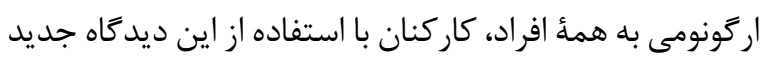

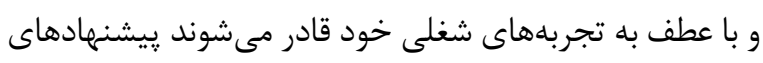
مناسب، عملى و ساده براى بهبود سازمان و شرايط محيط كار مطرح كنند. لذا يس از هماهنگى هاى نخستين با مسئولان مربوط تيم راهبرى متشكل از • ا نفر عضو با توجه به تجربه

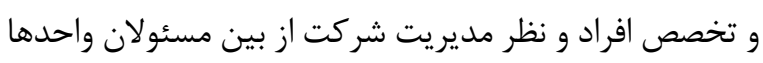
تشكيل شد. نقش اعضاى اين تيم هدايت فعاليتها و ارتباط

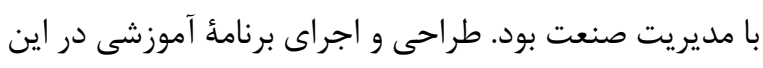

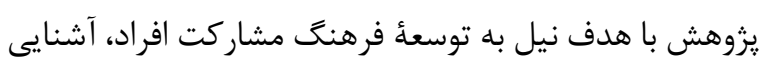
جدول ا. راهنماى انتخاب خكسليست مناطق كارى مشكل بـدار

$\begin{array}{ccc}1 & r & r \\ 1-1 . & 91-1 . & 41-8\end{array}$

$r+r$

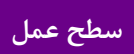

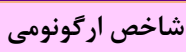

r درصد مبتلايان به ضايعه در ششماهئ اول سالهاى عqب

\section{بافتهها}

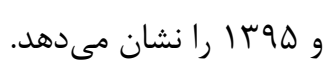

جدول شماره r درصد مبتلايان به ضايعه را در ششماهـ اول سال ه9 در مقايسه با ششماهؤ اول سال 9 ه نشان مى دهد. نتايج نشان مى دهد تعداد افرادى كه به ناراحتى دجار شدهاند كاهش يافته است. نتايج حاصل از فهرست بازبينى نئ دهان تكميلى قبل و بعد از به كارگيرى نكات بازبينى و اثرات آن به تفكيك 9 شاخه در جدول ب آمده است.

نتايج حاصل از تحليل آمارى دادهها نشان داد ميانخين

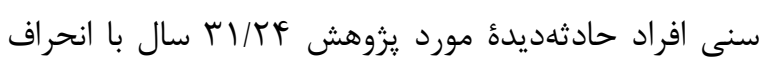
معيار له/ و و در افراد حادثهنديده ميانگين سنى

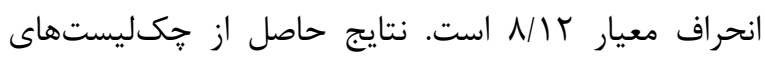

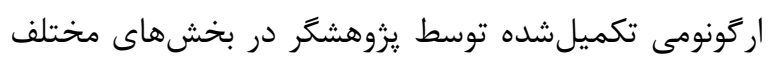
شركت نشان داد كه نمرهٔ كل FV/DF و نشاندهنده آن است كه شرايط ارگونومى در سطح عمل بـ قرار دارد. جدول شماره 
جدول r. درصد افر ادى از جامعه كه در ششماهئ اول سالهاى 9 و و هو به ناراحتىهاى مختلف دجار شدهاند.

\begin{tabular}{|c|c|c|c|}
\hline \multicolumn{2}{|c|}{ درصد مبتلايان به ضايعه } & \multirow{2}{*}{ شرح ضايعه } & \multirow{2}{*}{ رديف } \\
\hline ششماهؤ اول سال ه9 1 1 & ششماهؤ اول سال Iraf & & \\
\hline זr & QI & ضايعات كردنى & 1 \\
\hline rA & ra & ضايعات شانهاى & r \\
\hline 1. & re & ضايعات تحتانى يشت & $r$ \\
\hline r & re & ضايعات مج دست & f \\
\hline rI & r) & ناراحتى آرنج & $\Delta$ \\
\hline 19 & rt & ناحيه فوقانى يشت & 9 \\
\hline rI & rt & كفل/ ران ـ باسن & $\checkmark$ \\
\hline TY & rq & هر دو زانو & $\wedge$ \\
\hline 19 & r & هر دو قوزك پا & 9 \\
\hline
\end{tabular}

جدول ب. ميانكين و انحر اف معيار حيطههاى مختلف ايمنى، بهداشت و سلامت و شرايط كار قبل و بعد از بهكاركيرى نكات بازبينى و اثرات آن

\begin{tabular}{|c|c|c|c|}
\hline \multirow{2}{*}{ P-Value } & \multicolumn{2}{|c|}{ ميانكين انحراف } & \multirow{2}{*}{ وضعيت ايمنى، بهداشت، سلامت و شرايط كار } \\
\hline & بعد & قبل ق & \\
\hline$<\cdot / \cdot \cdot 1$ & $(9 / \wedge 9) 9) / \cdot \wedge$ & $(\mid \Delta / I) V \Delta / r \Delta$ & حمل و نكَهدارى مواد \\
\hline.$/ \cdot r$ & $(9 / r \vee) \wedge 9 / r r$ & $(1 \cdot / / \Delta) \wedge r / v$. & ابزار دستى \\
\hline $.1 \cdot 19$ & $(\mid Q / \Delta F) \wedge V / \& V$ & $(\mid 9 / \cdot r) V N / q$ & 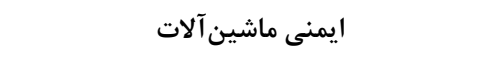 \\
\hline$\cdot 1 \cdot \cdot 1$ & $(\mid r / / Q) \wedge \varepsilon / 1 F$ & $(\mid F / \cdot r) \vee q / \wedge q$ & طراحى ايستخاه كار \\
\hline$\cdot / \cdot .1$ & $(1 \cdot / 1 \Lambda) 9 r / 94$ & $(\mid q / \cdot T) \wedge r / \Delta q$ & تأمين روشنايى \\
\hline$<\cdot / \cdot \cdot 1$ & $(1 \cdot / \Delta \Lambda) \wedge 9 / r r$ & $(I T / T T) \Lambda \cdot / \Lambda F$ & محوطه و ساختمان \\
\hline$<\cdot / \cdot \cdot 1$ & $(\Lambda / \Lambda \Lambda) q \cdot / \Gamma \Delta$ & $(\mid Q / / Y) V Q / / Q$ & عوامل و مواد خطرناك \\
\hline$\cdot / \cdot 1$ & $(1 \cdot / \mathrm{V}) \wedge \Lambda / q$. & $(\mid F / Q r) \Lambda \cdot / V I$ & تسهيلات رفاهى \\
\hline$\cdot 1 \cdot .1$ & $(\mid G / 9 T) \wedge V / \Delta T$ & $(\mid \Delta / r q) \Lambda \cdot / 9 \Delta$ & سازماندهى كار \\
\hline$<\cdot / \cdot \bullet \mid$ & $(৭ / \vee ९) \wedge \Lambda / \wedge 9$ & $(१ / ৭ 1) \wedge 1 / \vee ৭$ & كل شاخهها \\
\hline
\end{tabular}

روى شاخهُ بعدى تأثير افزايشى داشته و روى شاخئ قبلى هم بدين گونه اثر حذاشته است.

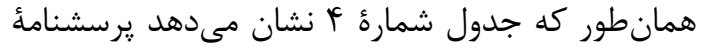
كيفيت زندگى كارى NIOSH را در دو مرحله شاغلان تكميل كردند و با استفاده از آزمون t زوجى تحليل شد. با توجه به سطح معنادارى بهدستآمده، تفاوت معنادار در كيفيت زندگى كارى در قبل و بعد از مداخله وجود دارد $(P<\cdot 1 \cdot \cdot 1)$ t همانطور كه در جدول شمارة r آمده، آزمون آمارى

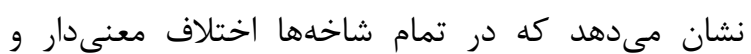
بيشترين اثر مربوط به شاخهُ حمل و نتحهدارى مواد و كمترين

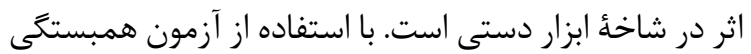

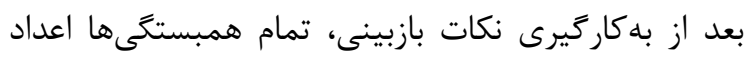

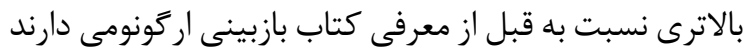

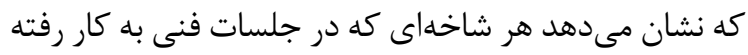

جدول F. مقايسهُ كيفيت زندكى كارى قبل و بعد از مداخله

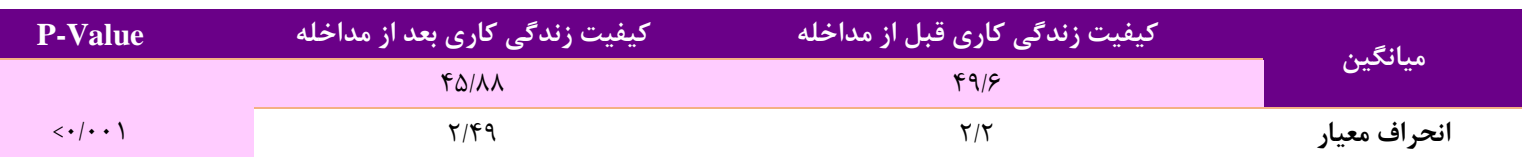


بودن اركونومى مشاركتى بر افزايش كيفيت زندكى شاغلان

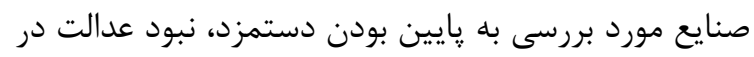

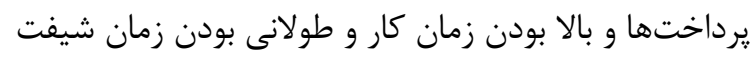

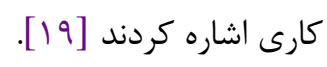

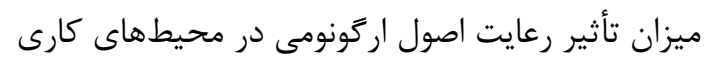

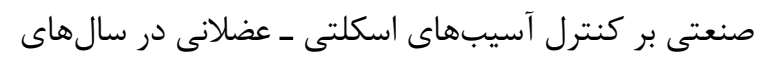

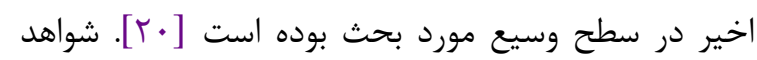

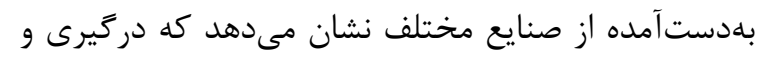

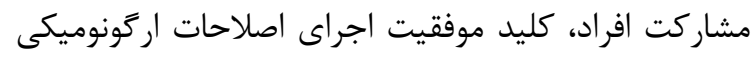
است. كاركنان دانش منحصربهفردى در مورد شغل خود

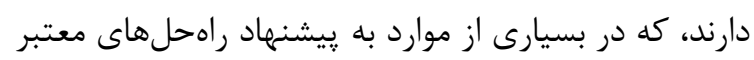

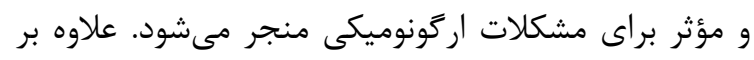

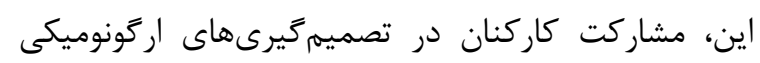
موجب ايجاد اعتماد، تعهد و حسن نيت است و به افزايش دارن

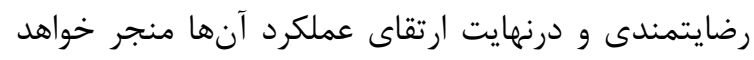

\section{نتيجه گيرى}

بنابراين توصيه مىشود براى بيشبرد اهداف اركونومى و

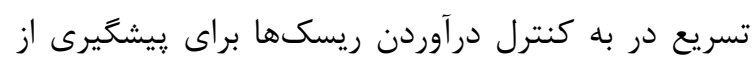

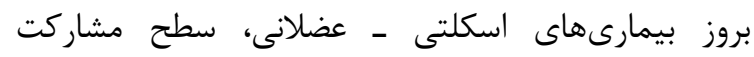

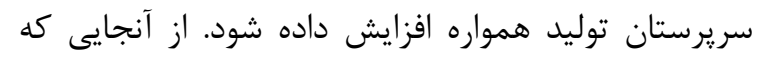
درصد بالايى از جمعيت كشور در صنايع مشغول به كارند و

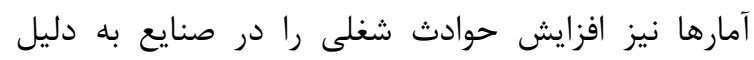
به كار كيرى ماشين آلات مختلف و سرعت بالاى توليد نشان

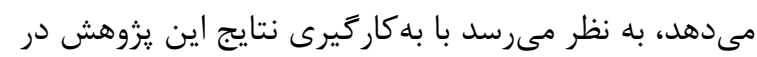

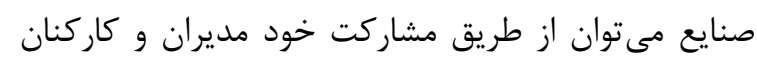
شاغل در صنعت ميزان حوادث را كاهش داد و درنتيجه سطح سلامت جامعأ كارى را حفظ كرد و ارتقا بخشيد. بيشنهاد

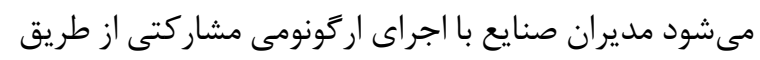

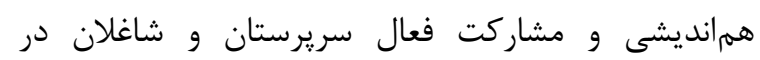
تصميمخيرىها و رفع نواقص و مشكلات شغلى، نقش

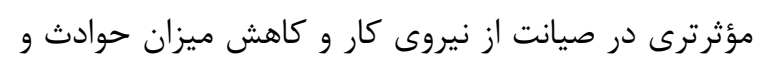

\section{بحث و نتيجه كيرى}

كرجه تاكنون تحقيقات متعدد، با استفاده از اركونومى

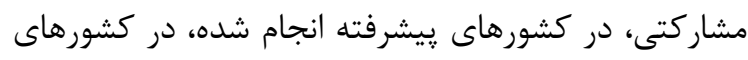
درحالتوسعه ازجمله ايران، توجه كمترى به آن شده و بررسىهاى انجامشده نيز معدود بوده است، بنابراين اين

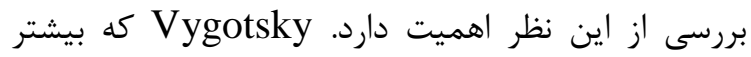
Zane of Proximal تحقيقاتش در مورد ابداع اعندين يا منطقة رشد مجاور است، بر Development (ZPD) نقش فرهنگ و تجربه تأكيد كرده و معتقد است تعامل اجتماعى باعث رشد ذهنى مىشود و همجنين زبان براى اهداف ارتباطى از طريق تعامل اجتماعى توسعه مىيابد رسيد

Wood و همكاران در سال 1979 نظريئ او را توسعه

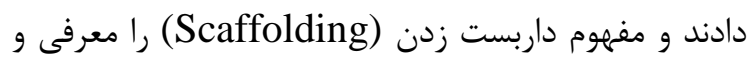
به اين مسئله اشاره كردند كه افراد بزر گسال، با آكاهى دادن

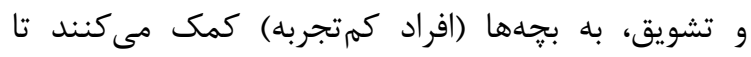

مهارتهاى شناختى آنها توسعه يابد [IV] براساس تحقيقات مورى و همكاران در زمينهُ تأثير به كار كيرى اركونومى مشار كتى، مشاهده شد كه به كاركيرى اركونومى مشاركتى باعث افزايش جشمخير كيفيت محصول

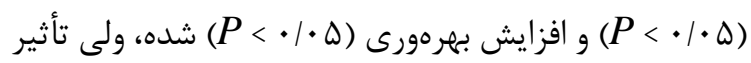

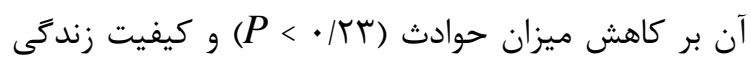
كارى (II/ = P Pنفى بوده است، اين محققان در بررسى نتايج مربوط به كاهش ميزان حوادث و كيفيت زندكى كارى به اين نكته اشاره كردند كه مهمهترين هدف مديريت ارشد

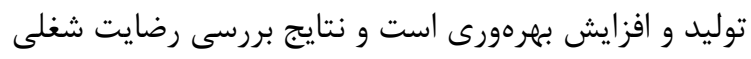

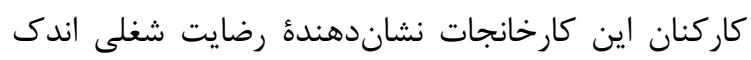

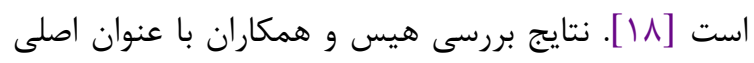

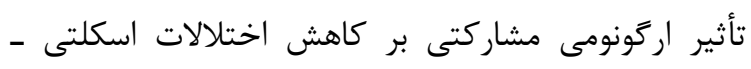
عضلانى و كيفيت زندكى كارى با نتايج اين بررسى مغاير

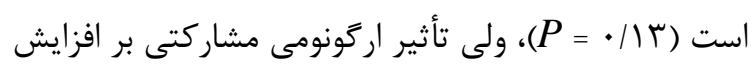

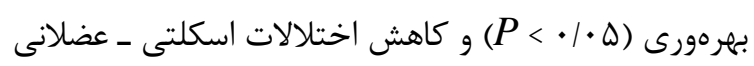
(ه) مشهود است. محققان در بررسى علل غير مؤثر 


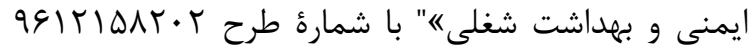

$$
\begin{aligned}
& \text { استخراج شده و مجريان يزوهش بدينوسيله مراتب تشكر و } \\
& \text { قدردانى خود را از آن مركز اعلام مىدارند. } \\
& \text { تعارض منافع }
\end{aligned}
$$$$
\text { بين نويسندَان هيجزَّنه تعارضى در منافع وجود ندارد }
$$

\section{References}

1. Helali F, Lönnroth E-C, Shahnavaz H. Participatory ergonomics intervention in an industrially developing country - a case study. Int J Occup Saf Ergon. 2008;14(2):159-76. https://doi.org/10.1080/10803548.2008.11076760 PMID: 18534152

2. Sadeghi S. Introduction to the principles of ergonomics. Tehran, Chehr publication 2006.

3. Helali F. Using Ergonomics Checkpoints to Support a Participatory Ergonomics Intervention in an Industrially Developing Country (IDC)-A Case Study. Int J Occup Saf Ergon. 2009;15(3):325-37. https://doi.org/10.1080/10803548.2009.11076811

4. Salvendy G. Handbook of Human Factors and Ergonomics. New York: Wiley; 1997. p.490-513

5. Helali F. Developing an Ergonomics Intervention Technique Model to Support the Participatory Ergonomics Process for Improving Work Systems in Organizations in an Industrially Developing Country and its 'Meta-Reflection' [doctoral thesis]. Luleå, Sweden: Luleå University of Technology; 2008.

6. Nagamachi M. Requisites and practices of participatory ergonomics. Int J Ind Ergon. 1995;15(5):371-7. https://doi.org/10.1016/01698141(94)00082-E

7. M H. The Relationship among Quality of Work Life, Organizational Commitment, and Organizational Citizenship Behavior- A Study of High Technology Industry: National Chung Shan University; 2000.

8. Hamidi Y, Mohammadi A, Soltanian A R, Mohammad Fam I. Organizational Culture and Its Relation with Quality of Work Life in University Staff. J Ergon. 2016;3(4):30-8.

9. Hamidi Y, Mortezaei M, Heidari Pahlavian A, Soltanian A R, Heidari Moghaddam R. The Relationship among Quality of Work Life, Participation and Stress Levels in Health Center Workers. J Ergon. 2015;2(4):18-24.

10. Heydari Moghadam R, Motamedzade M, Babamiri M, Roshanayi Q, Rastegari Yekta S, Zandkarimi E. The Effects of Motor Interventions on the Quality of Working Life of Female Hairdressers with Varicose Veins Disease in Hamadan . J Ergon. 2016;4(3):59-65.

$$
\begin{aligned}
& \text { ارتقاى سطح سلامت جامعأ كارى و شكوفايى اقتصاد كشور } \\
& \text { ايفا كنند. } \\
& \text { تقدير و تشكر } \\
& \text { اين يزوهش با حمايت مالى مركز تحقيقات بهداشت و }
\end{aligned}
$$

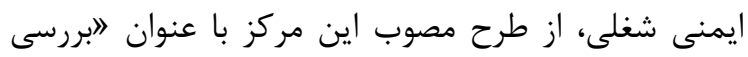

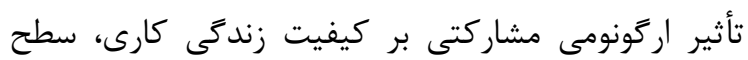

11. Fathi $\mathrm{K}$, Ghorbani F, Heidari moghadam R, Mojtahedi H. effect of 6 week aerobic step training on cardiovascular fitness, body composition,flexibility, anaerobic power and quality of life of female students of isfahan university. J Ergon. 2014;2(2):29-37.

12. Brauer RL. Safety and Health for Engineers. Translate: Halvani Gh. Tehran: Sobhan; 2007.

13. Vygotsky LS. Mind in Society: The Development of Higher Psychological Processes. Cambridge, MA: Harvard University Press; 1978.

14. Wood D, Bruner JS, Ross G. The role of tutoring in problem solving. J Child Psychol Psychiatry. 1976;17(2):89-100.

https://doi.org/10.1111/j.14697610.1976.tb00381.x PMID:932126

15. Moore JS, Garg A. The effectiveness of participatory ergonomics in the red meat packing industry evaluation of a corporation. Int J Ind Ergon. 1998;21(1):47-58. https://doi.org/10.1016/S0169-8141(97)00024-3

16. Hess JA, Hecker S, Weinstein M, Lunger M. A participatory ergonomics intervention to reduce risk factors for low-back disorders in concrete laborers. Appl Ergon. 2004;35(5):427-41. https://doi.org/10.1016/j.apergo.2004.04.003 PMID: 15246881

17. M M. Survey Statistic of Occupatinal accidents and its Relationship with the victims of Employment in the First 6 Month at 89 years of steel building Project. Gazvin2010. 